\title{
Protocol
}

\section{In Vitro Screening for Regulated Transcription Factors with Differential Display of DNA-Binding Proteins (DDDP)}

\author{
Hans Reinke and Ueli Schibler ${ }^{1}$ \\ Department of Molecular Biology, University of Geneva, CH-1211 Geneva, Switzerland
}

\section{INTRODUCTION}

Strict regulation of transcription factor activity is essential to establish and maintain gene expression. Eukaryotic cells control transcription factors at many different levels. Post-translational regulatory mechanisms (e.g., phosphorylation, nuclear translocation, multimerization, regulated degradation, etc.) play particularly important roles because they enable cells to respond to various intra- and extracellular stimuli quickly and without prior protein synthesis. However, extensive post-translational changes can make it difficult to identify differentially regulated transcription factors. Common genomic screening techniques such as DNA microarray analysis are unable to detect any mode of regulation beyond that of mRNA stability. This protocol describes the differential display of DNA-binding proteins (DDDP), which is based on the electrophoretic mobility shift assay (EMSA) and detects DNAbinding transcription factors, independent of the number or nature of regulatory steps required for activation. DDDP is an unbiased screening technique that can be used in any experimental system that uses concentrated protein extracts. A plasmid library containing random DNA sequences is constructed. This library is then used to generate radioactive DNA probes to test protein extracts from different sources in parallel for differentially regulated DNA-binding proteins. Plasmids corresponding to probes that display differential DNA-binding activity can be sequenced, and the binding sequence can be narrowed down in a two-step procedure. The corresponding transcription factors can then be identified by bioinformatic and/or biochemical methods.

\section{RELATED INFORMATION}

Reinke et al. (2008) provides more information about the DDDP technique and explains in detail the rationale for using a random DNA library, including the underlying calculations.

\section{MATERIALS}

CAUTIONS AND RECIPES: Please see Appendices for appropriate handling of materials marked with $<!>$, and recipes for reagents marked with $<\mathbf{R}>$.

\section{Reagents}

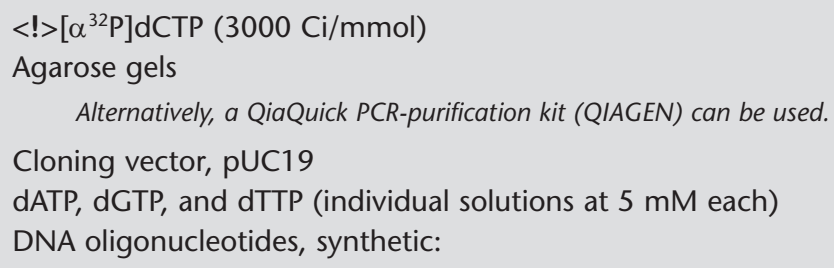




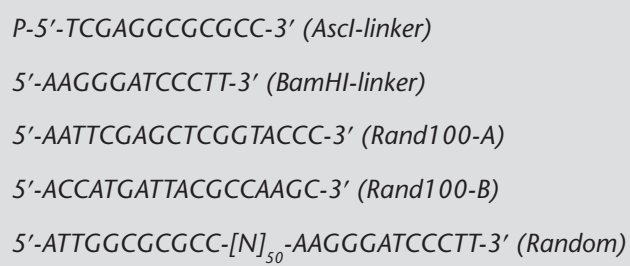

Prepare concentrated protein (preferably nuclear) extracts from different cell/tissue sources as required for comparative studies (e.g., wild-type vs. mutant cell lines, normal vs. cancer cells, cells at different stages of development, tissues harvested from subjects at different time points for circadian studies, etc.).

Reagents for sequencing plasmids

Restriction enzyme incubation buffers (10X)

Restriction enzymes: Sall, Ascl and BamHI

\section{Equipment}

Beaker (glass) containing $100 \mathrm{~mL}$ of boiling $\mathrm{H}_{2} \mathrm{O}$

Equipment for running agarose and polyacrylamide gels

Equipment for sequencing plasmids

Filter paper (Whatman)

Gel dryer

Heating block preset to $75^{\circ} \mathrm{C}$

Ice

Microcentrifuge

PCR machine

Pipettors and tips

Tubes (microcentrifuge, normal and screw-top)

Vortex mixer

X-ray film and cassettes (or Phosphorlmager system)

\section{METHOD}

\section{Generation of an Ordered Random DNA Library}

See Figure 1 for an outline of the cloning procedure.

1. Construct the vector pUC19-Ascl by cloning the 5'-phosphorylated oligonucleotide Ascl-linker into the Sall site of the cloning vector pUC19.

2. Resuspend the DNA oligonucleotide Random to a concentration of $100 \mu \mathrm{M}$ in $100 \mathrm{mM} \mathrm{NaCl}$ in a screw-top microcentrifuge tube. Place the tube into a beaker containing $100 \mathrm{~mL}$ of boiling $\mathrm{H}_{2} \mathrm{O}$. Cool the $\mathrm{H}_{2} \mathrm{O}$ in the cold room over the course of several hours to $4^{\circ} \mathrm{C}$.

Store the self-annealed oligonucleotide Random at $-20^{\circ} \mathrm{C}$. Always keep it on ice during future manipulations to prevent dissociation and imperfect reannealing.

3. Working on ice, prepare the following reaction mixture:

$124 \mu \mathrm{L}$ of $\mathrm{H}_{2} \mathrm{O}$

$15 \mu \mathrm{L}$ of $10 \mathrm{X}$ Klenow fill-in buffer 


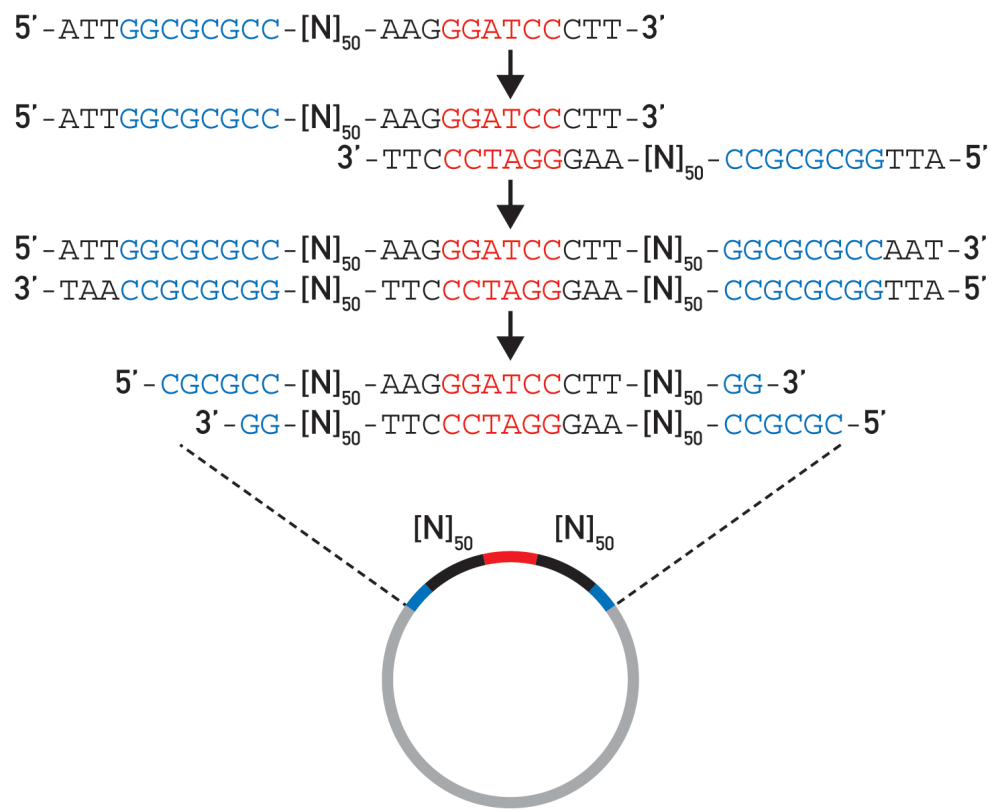

FIGURE 1. Construction of the random DNA library. Oligonucleotides with 50 random nucleotide positions $\left([\mathrm{N}]_{50}\right.$ ), a $5^{\prime}-$ flanking region containing an Ascl restriction site (blue), and a palindromic 3'-flanking region containing a BamHI restriction site (red), are self-annealed, rendered double-stranded, and cloned into the Ascl site of a bacterial plasmid vector. (For color figure, see doi: 10.1101/pdb.prot5028 online at www.cshprotocols.org.)
$1.2 \mu \mathrm{L}$ of dNTP mix
$5 \mu \mathrm{L}$ of self-annealed Random DNA oligonucleotide
$5 \mu \mathrm{L}$ of Klenow fragment.

4. Incubate for $30 \mathrm{~min}$ at room temperature.

5. Incubate for $20 \mathrm{~min}$ at $75^{\circ} \mathrm{C}$ to inactivate the Klenow fragment.

6. Cut the double-stranded DNA fragment with the restriction enzyme Ascl in the corresponding restriction buffer.

7. Purify the cut DNA fragment on an agarose gel.

8. Ligate the purified DNA fragment into the bacterial vector pUC19-Ascl.

9. Prepare DNA minipreps:

i. Prepare at least 110 clones to perform a screen in a eukaryotic system. Number clones serially.

ii. Sequence the inserts from five to 10 clones to verify that they all contain different inserts of the correct size.

See Troubleshooting.

iii. Keep only clones with a single insert. Store at $-20^{\circ} \mathrm{C}$ for later use.

\section{Generation of Radioactive EMSA Probes}

See Figure 2 for an outline of the procedure for generating the EMSA probes.

10. Amplify each clone of the DNA library in a $100-\mu \mathrm{L}$ standard PCR reaction with the primers Rand100-A and Rand100-B using the following program:
1 cycle
$1.5 \mathrm{~min}$ at $95^{\circ} \mathrm{C}$
30 cycles
$30 \mathrm{sec}$ at $95^{\circ} \mathrm{C}$
$30 \mathrm{sec}$ at $55^{\circ} \mathrm{C}$
$30 \mathrm{sec}$ at $72^{\circ} \mathrm{C}$
1 cycle
$5 \mathrm{~min}$ at $72^{\circ} \mathrm{C}$ 


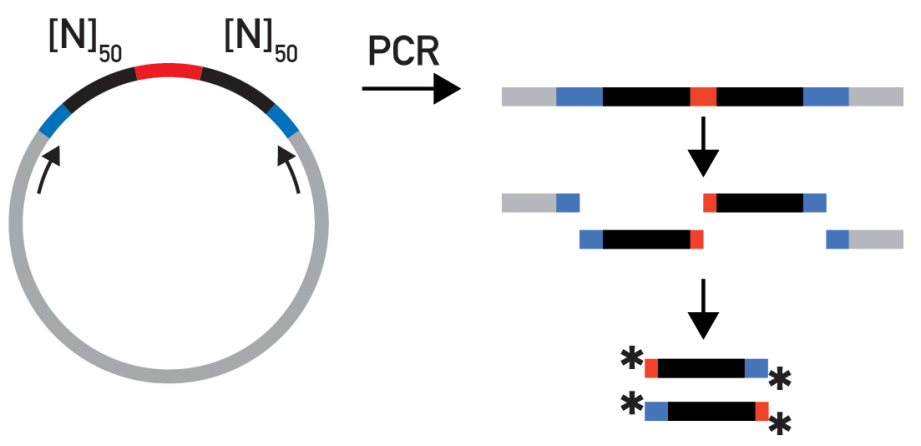

FIGURE 2. Generation of EMSA probes from individual clones of the random DNA library. Random DNA inserts are amplified by PCR, digested with $\mathrm{Ascl}$ and $\mathrm{BamHI}$, and radioactively labeled by the incorporation of $\left[\alpha^{32} \mathrm{P}\right] \mathrm{dCTP}$ (asterisks). (For color figure, see doi: 10.1101/pdb.prot5028 online at www.cshprotocols.org.)

11. Purify at least $500 \mathrm{ng}$ of each PCR product on an agarose gel.

12. Digest the purified PCR products with the restriction enzymes Ascl and BamHI in their corresponding restriction buffers.

13. Adjust the concentrations of digested DNA fragments to $\sim 10 \mathrm{ng} / \mu \mathrm{L}$ with $\mathrm{H}_{2} \mathrm{O}$. Concentrate the samples if necessary.

14. Chill $3 \mu \mathrm{L}$ each of the digested DNA fragments in microcentrifuge tubes on ice.

15. For each set of six probes to be labeled, mix (on ice) the following:

$3 \mu \mathrm{L}$ of Klenow fill-in buffer

$0.5 \mu \mathrm{L}$ each of $5 \mathrm{mM}$ dATP, dGTP, and dTTP

$1.5 \mu \mathrm{L}$ of $\left[\alpha^{32} \mathrm{P}\right] \mathrm{dCTP}$

$1.5 \mu \mathrm{L}$ of Klenow fragment

This amount can be scaled up. However, label at least six probes at the same time to avoid pipetting of extremely small volumes.

16. Add $1 \mu \mathrm{L}$ of the Klenow/nucleotide solution to each tube containing the DNA fragments. Incubate for $15 \mathrm{~min}$ at room temperature.

17. Add $95 \mu \mathrm{L}$ of $75 \%$ ethanol at room temperature to each tube. Vortex.

18. Centrifuge for $5 \mathrm{~min}$ at room temperature in a microcentrifuge to separate unincorporated radioactivity from the probes.

19. Discard the supernatant. Dry the pellets for $5 \mathrm{~min}$ at room temperature.

20. Resuspend the pellets in $10 \mu \mathrm{L}$ of $\mathrm{H}_{2} \mathrm{O}$.

The specific activity of the probe should be $\sim 10^{7} \mathrm{dpm} / \mu \mathrm{g} D N A$. Radioactively labeled probes can be stored at $-20^{\circ} \mathrm{C}$.

\section{Differential Display}

21. Prepare a set of tubes such that each protein extract to be tested can be incubated with each of the radiolabeled probes from Step 20.

22. Working on ice, mix the following:

$5 \mu \mathrm{g}$ of protein extract (typically in a volume of $0.7-2.5 \mu \mathrm{L}$ )

$2 \mu \mathrm{L}$ of $5 \mathrm{X}$ EMSA binding buffer

$1 \mu \mathrm{L}$ of a radiolabeled probe from Step 20

Add $\mathrm{H}_{2} \mathrm{O}$ to a total volume of $10 \mu \mathrm{L}$. 
Depending on the type of transcription factors expected, or if a screen for proteins with specific cofactor requirements has been performed, extra salts, cofactors, energy, etc., can be added to the binding reaction. The concentrations of nonspecific competitors (salmon sperm DNA and poly[dl-dC]) used here are only approximate values and should be optimized for each set of extracts and/or binding conditions. Adjust the amount of competitor such that each lane displays several readily distinguishable protein-DNA complexes (e.g., Fig. 3).

23. Incubate for $15 \mathrm{~min}$ at room temperature. Add $1 \mu \mathrm{L}$ of EMSA loading buffer.

24. Load the reactions containing the same radioactive probe but different protein extracts next to each other on a $4 \%$ polyacrylamide gel (see Fig. 3).

25. Run the gel at $7.5 \mathrm{~V} / \mathrm{cm}$ for $2.5-3 \mathrm{~h}$ at room temperature.

26. Vacuum-dry the gel on Whatman paper. Expose to X-ray film or a Phosphorlmager screen.

27. Identify differentially binding transcription factors on the images. Sequence the corresponding plasmids to obtain the sequences of their binding sites.

See Troubleshooting.

\section{Narrowing Down Binding Sites}

To facilitate further sequence analysis, this two-step procedure can be used to narrow down the exact position of a binding site within a random probe from $100 \mathrm{bp}$ to 10-30 bp. It is usually sufficient to use only one protein extract for these procedures. Only use other extracts for side-by-side comparisons if in doubt as to the identity of the band showing differential binding activity

28. For a given insert of interest, separately amplify by PCR the two 50-bp random DNA regions, using the oligonucleotide BamHI-linker in combination with Rand100-A and Rand100-B, respectively. Use the following program:

$\begin{array}{llll}1 \mathrm{cycle} & 1.5 \mathrm{~min} \text { at } 95^{\circ} \mathrm{C} & & \\ 3 \text { cycles } & 30 \mathrm{sec} \text { at } 95^{\circ} \mathrm{C} & 30 \mathrm{sec} \text { at } 45^{\circ} \mathrm{C} & 30 \mathrm{sec} \text { at } 72^{\circ} \mathrm{C} \\ 3 \text { cycles } & 30 \mathrm{sec} \text { at } 95^{\circ} \mathrm{C} & 30 \mathrm{sec} \text { at } 48^{\circ} \mathrm{C} & 30 \mathrm{sec} \text { at } 72^{\circ} \mathrm{C} \\ 3 \text { cycles } & 30 \mathrm{sec} \text { at } 95^{\circ} \mathrm{C} & 30 \mathrm{sec} \text { at } 51^{\circ} \mathrm{C} & 30 \mathrm{sec} \text { at } 72^{\circ} \mathrm{C} \\ 21 \mathrm{cycles} & 30 \mathrm{sec} \text { at } 95^{\circ} \mathrm{C} & 30 \mathrm{sec} \text { at } 54^{\circ} \mathrm{C} & 30 \mathrm{sec} \text { at } 72^{\circ} \mathrm{C} \\ 1 \mathrm{cycle} & & & 5 \mathrm{~min} \text { at } 72^{\circ} \mathrm{C}\end{array}$

29. Working on ice, mix the following:
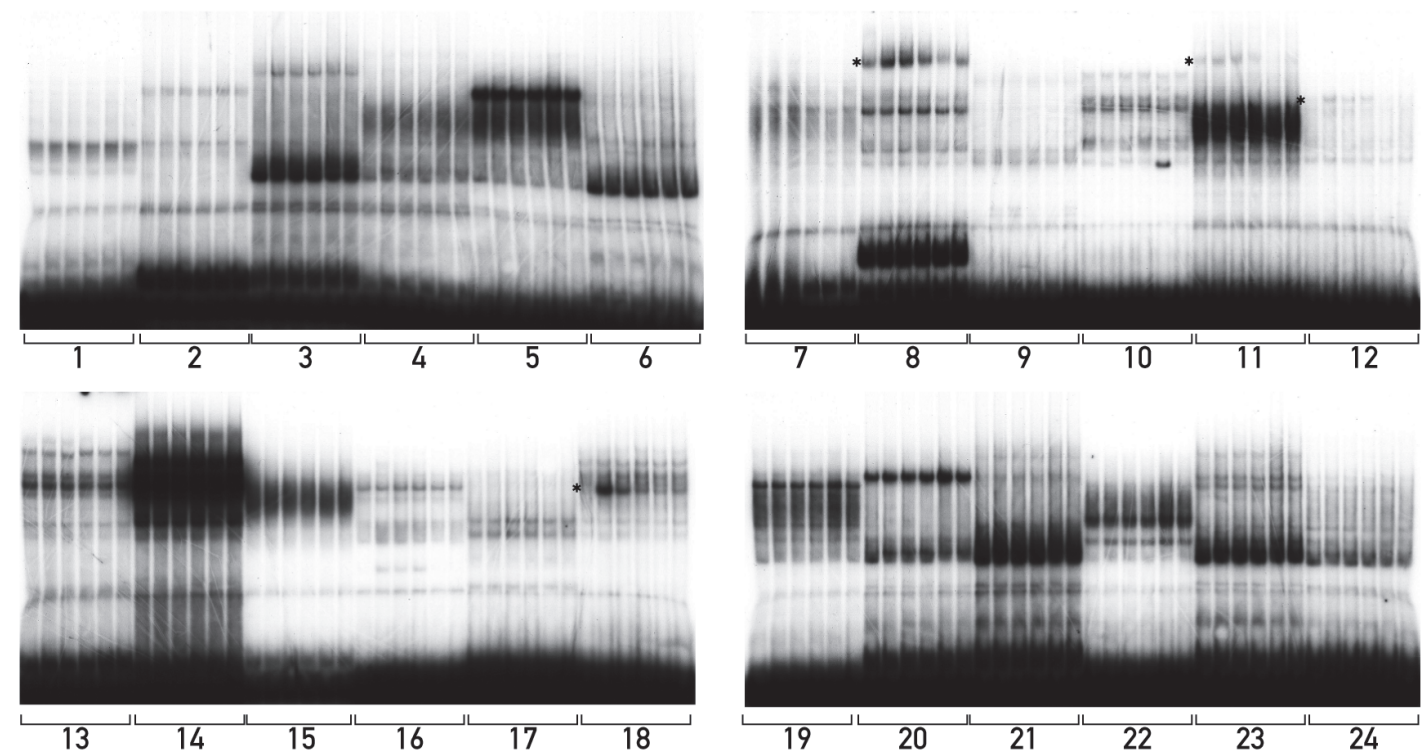

FIGURE 3. Four typical gels from a DDDP screen. Each autoradiograph displays groups of EMSAs performed on six nuclear extracts harvested from mouse livers at 4-h intervals over a 24-h period with six random DNA probes each (labeled 1-24). Prominent differences in DNA-binding activities were identified with probes 8, 11, 12, and 18 (asterisks). 
$5 \mu \mathrm{g}$ of protein extract

$2 \mu \mathrm{L}$ of $5 \mathrm{X}$ EMSA binding buffer

500 ng of nonradiolabeled PCR product (as competitor DNA)

Add $\mathrm{H}_{2} \mathrm{O}$ to a total volume of $10 \mu \mathrm{L}$.

Assay each $P C R$ product separately.

30. Incubate for $10 \mathrm{~min}$ at room temperature. Add $1 \mu \mathrm{L}$ of the radiolabeled probe of interest. Perform EMSAs as described in Steps 23-27.

31. Design six 20-bp oligonucleotides spanning the sequence of the competing fragment such that each oligonucleotide overlaps its counterpart on the opposite strand by $10 \mathrm{bp}$ (Fig. 4A).

32. Anneal the oligonucleotides with each other in various combinations. Generate double-stranded oligonucleotides by fill-in with Klenow polymerase (Fig. 4B).

33. Use the double-stranded oligonucleotides as competitor DNA in EMSAs as described in Steps 29 and 30 to identify the minimal double-stranded sequence needed to compete with the radiolabeled probe.

\section{TROUBLESHOOTING}

Problem: Many clones of the random DNA library contain inserts that are too small and contain less than $100 \mathrm{bp}$ of random DNA.

[Step 9.ii]

Solution: The Random DNA oligonucleotide might not have self-annealed correctly. Avoid warming the annealed oligonucleotide before adding the Klenow fragment.

Problem: Most of the bands on the EMSA gel show only a black smear or show no protein binding at all.

[Step 27]

Solution: The EMSA reactions contain either too much or too little nonspecific competitor. Make a titration series with three to five random probes to determine the ideal amount of competitor DNA.

\section{DISCUSSION}

Various methods exist to identify differential transcription factor activity in an unbiased way. Genomic screening methods like DNA microarray analysis or serial analysis of gene expression are powerful techniques to detect differences in steady-state mRNA levels (Velculescu et al. 1995; De Haro and Panda 2006). However, many transcription factors are regulated extensively at the post-transcriptional and/or post-translational levels. Proteomic methods can, in principle, be used to screen for transcription factor regulation at the protein level. However, these methods are generally ineffective at detecting transcription factors because of the low levels at which these proteins are expressed (Reddy et al. 2006). DDDP complements these methods by using an activity assay to select specifically for transcriptionally competent DNA-binding proteins.
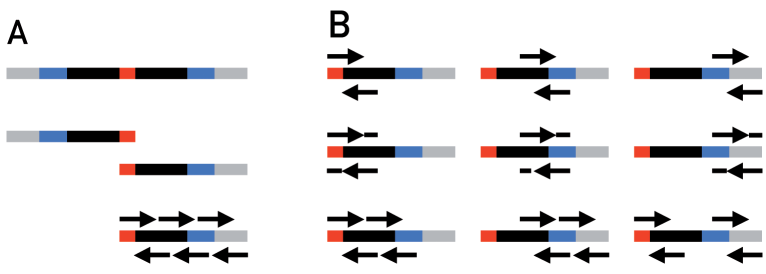

FIGURE 4. Strategy to identify an unknown binding site in random DNA probes. (A) Two 50-bp random DNA sequences derived from a random DNA insert are amplified separately by PCR and used as competitor DNA in EMSA experiments against the original probe. Six oligonucleotides (arrows) are then designed for the competing fragment. (B) The oligonucleotides are then used in competition experiments individually or in combination with each other, annealed or filled in, as shown. (For color figure, see doi: 10.1101/pdb.prot5028 online at www.cshprotocols.org.) 
A key feature of DDDP is the use of a random DNA library, which enables the screening of a maximum number of potential DNA-binding sites within a minimum length of DNA sequence. The question arises: What is the chance of finding functional binding sites in synthetic DNA sequences that have not been evolutionarily tuned for efficient transcription factor binding? Transcription factors have, in general, a very high affinity for their binding sites. We have shown previously that a single mismatch in a transcription factor recognition site reduces its binding affinity by, at most, one order of magnitude (Fonjallaz et al. 1996). Therefore, most factors should also bind to such imperfect binding sites. Consequently, this reduces greatly the number of binding sites that have to be present in the library. As outlined in greater detail (Reinke et al. 2008), if one allows for at most one mismatch in the binding site, a binding site for a typical eukaryotic transcription factor can still be found (with a probability of more than $99 \%$ ) in as few as 11,000 bps of random DNA sequence (Fig. 5).

Like any other screening method, DDDP has its limitations. Successful use of DDDP only identifies a binding site, not the transcription factor itself. Nevertheless, after narrowing down the binding site, bioinformatic methods can greatly facilitate the identification of the corresponding transcription factor. Alternatively, the DNA probe obtained by the screen can be used to track the protein as it is purified biochemically, or it can be used directly in an affinity purification procedure (Kadonaga and Tjian 1986). Unfortunately, DDDP cannot be performed in saturating conditions. Also, different transcription factors can have different requirements (e.g., salt concentration, temperature, cofactors, etc.) for DNA binding. Nevertheless, DDDP can be used in any biological system that allows for the preparation of concentrated protein extracts. It is also a relatively inexpensive genome-wide screening method that can be performed easily in any normally equipped molecular biology laboratory.

$\frac{1}{2} \frac{1}{4} \frac{1}{2} \quad \frac{1}{4} \frac{1}{2} \frac{1}{4} \frac{1}{4} \frac{1}{4} \frac{1}{4} \frac{1}{4}$

REV-ERBa: 5' - W A W N T R G G T C A - 3'

$\frac{1}{2} \frac{1}{4} \frac{1}{4} \frac{1}{4} \frac{1}{2} \frac{1}{4} \frac{1}{4} \frac{1}{4} \frac{1}{4} \frac{1}{2}$

PAR bZIP: 5' - R T T A Y G T A A Y - 3'

$$
\begin{aligned}
& F_{p m}=2\left(\frac{1}{2}\right)^{3}\left(\frac{1}{4}\right)^{7}=\frac{1}{65,536} \\
& F_{\mathrm{mm}}=3\left(2 F_{p m}\right)+7\left(3 F_{p m}\right)=27 F_{p m} \\
& F_{\text {total }}=\frac{F_{p m}+F_{\mathrm{mm}}}{65,536}=\frac{28}{65,536}=\frac{1}{2341} \\
& p=0.99=1-\left(\frac{2340}{2341}\right)^{n} \\
& n=10,778
\end{aligned}
$$

FIGURE 5. Frequency of imperfect transcription factor binding sites in a random DNA library. Consensus binding sites for REV-ERB $\alpha$ and PAR bZIP proteins show the probability for each nucleotide position in random DNA. The calculations determine the number of base pairs $(n)$ that must be tested in random DNA to obtain with a probability $(p)$ of more than $99 \%$ a binding site with a complexity equal to that of a REV-ERB $\alpha$ or PAR bZIP binding site if a single mismatch is allowed. The total frequency $\left(F_{\text {total }}\right)$ of such binding sites is a function of the frequency of a perfect match $(F$ ) plus the frequency of all sequences with one mismatch $\left(F_{\mathrm{mm}}\right)$.

\section{REFERENCES}

De Haro, L. and Panda, S. 2006. Systems biology of circadian rhythms: An outlook. J. Biol. Rhythms 21: 507-518.

Fonjallaz, P., Ossipow, V., Wanner, G., and Schibler, U. 1996. The two PAR leucine zipper proteins, TEF and DBP, display similar circadian and tissue-specific expression, but have different target promoter preferences. $E M B O$ J. 15: 351-362.

Kadonaga, J.T. and Tjian, R. 1986. Affinity purification of sequencespecific DNA binding proteins. Proc. Natl. Acad. Sci. 83: 58895893.

Reddy, A.B., Karp, N.A., Maywood, E.S., Sage, E.A., Deery, M.,
O'Neill, J.S., Wong, G.K., Chesham, J., Odell, M., Lilley, K.S., et al. 2006. Circadian orchestration of the hepatic proteome. Curr. Biol. 16: 1107-1115.

Reinke, H., Saini, C., Fleury-Olela, F., Dibner, C., Benjamin, I.J., and Schibler, U. 2008. Differential display of DNA-binding proteins reveals heat-shock factor 1 as a circadian transcription factor. Genes \& Dev. 22: 331-345.

Velculescu, V.E., Zhang, L., Vogelstein, B., and Kinzler, K.W. 1995 Serial analysis of gene expression. Science 270: 484-487. 


\section{In Vitro Screening for Regulated Transcription Factors with Differential Display of DNA-Binding Proteins (DDDP)}

Hans Reinke and Ueli Schibler

Cold Spring Harb Protoc; doi: 10.1101/pdb.prot5028

\begin{tabular}{|c|c|}
\hline $\begin{array}{r}\text { Email Alerting } \\
\text { Service }\end{array}$ & Receive free email alerts when new articles cite this article - click here. \\
\hline $\begin{array}{l}\text { Subject } \\
\text { Categories }\end{array}$ & $\begin{array}{l}\text { Browse articles on similar topics from Cold Spring Harbor Protocols. } \\
\text { Characterization of Proteins (208 articles) } \\
\text { DNA:Protein Interactions ( } 74 \text { articles) } \\
\text { Electrophoresis of Proteins ( } 97 \text { articles) } \\
\text { Electrophoresis, general (130 articles) } \\
\text { High-Throughput Analysis, general (155 articles) } \\
\text { Libraries ( } 147 \text { articles) } \\
\text { Libraries, general (113 articles) } \\
\text { Molecular Biology, general (1293 articles) } \\
\text { Protein Identification and Analysis (202 articles) } \\
\text { Proteins and Proteomics, general (575 articles) } \\
\text { Proteome Analysis (56 articles) }\end{array}$ \\
\hline
\end{tabular}

